\title{
Production of 2-Hydroxyparaconic and Itatartaric Acids by Ustilago cynodontis and Simple Recovery Process of the Acids
}

\author{
Elvira D. GuevarRA* and Takeshi TABUCHI** \\ Institute of Applied Biochemistry, University of Tsukuba, \\ Tsukuba, Ibaraki 305, Japan \\ Received March 27, 1990
}

\begin{abstract}
Ustilago cynodontis $\mathrm{K} 320$ was selected as the best strain for the production of $l$-itatartaric acid and its lactone, $l$-2-hydroxyparaconic acid, in shake culture under acidic conditions. Factors affecting the acid production were examined to optimize the culture conditions for maximal production of itatartaric and 2-hydroxyparaconic acids and efforts were made to simplify the recovery of the acids. Fermentation in a jar was continued until the accumulated itaconic acid and erythritol were completely consumed. 2-Hydroxyparaconic acid (49 g) was easily recovered as a crystalline mass (about $96 \%$ in purity) from 11 of the culture filtrate by a process consisting of concentration, lactonization of itatartaric acid to 2-hydroxyparaconic acid, and ethyl acetate extraction. Sodium itatartarate was prepared from the recovered 2-hydroxyparaconic acid by saponification.
\end{abstract}

Our preceding paper ${ }^{1)}$ reported that several strains of genus Ustilago produced $l$-itatartaric acid (ITT) and its lactone, l-2-hydroxyparaconic acid (HP), in considerable amounts together with itaconic acid (IT) from glucose. The recovery of large amounts of $\mathrm{HP}$ or ITT from culture filtrates was reported to be laborious and difficult. ${ }^{2,3)}$

This paper describes studies on optimization of the culture conditions, especially on medium composition with minimized concentrations of nutrients for the maximal production of $\mathrm{HP}$ or ITT and the course of fermentation by a selected strain of $U$. cynodontis. A simple process of product recovery was also described, together with the kinetics of equilibrium reactions between HP and ITT.

\section{Materials and Methods}

Microorganisms. Twelve strains of Ustilago cynodontis and $U$. rabenhorstina IFO 8995 were used in a screening study, because they all were the producers of HP and ITT. ${ }^{1}$
U. cynodontis $\mathrm{K} 320$ was selected as the best producer of $\mathrm{HP}$ and, hence exclusively used in subsequent experiments.

Media and culture conditions. The following three fermentation media were used. Medium A: $12.0 \%$ glucose, $0.21 \% \mathrm{NaNO}_{3}, 0.05 \% \mathrm{KH}_{2} \mathrm{PO}_{4}, 0.02 \% \mathrm{MgSO}_{4} \cdot 7 \mathrm{H}_{2} \mathrm{O}$, 10 ppm $\mathrm{FeSO}_{4} \cdot 7 \mathrm{H}_{2} \mathrm{O}$, and $0.1 \%$ yeast extract (Oriental Yeast Co.) in tap water. Medium B: $12.0 \%$ glucose, $0.21 \%$ $\mathrm{NaNO}_{3}, 4 \mathrm{mM} \mathrm{NaH} \mathrm{PO}_{4}, 4 \mathrm{mM} \mathrm{KCl}, 0.8 \mathrm{~mm} \mathrm{MgSO}+7-$ $\mathrm{H}_{2} \mathrm{O}, 5 \mathrm{ppm} \mathrm{FeSO} \cdot 7 \mathrm{H}_{2} \mathrm{O}$, and 0.5 ppm $\mathrm{ZnSO}_{4} \cdot 7 \mathrm{H}_{2} \mathrm{O}$ in tap water. Medium C: $12.0 \%$ glucose, $0.10 \%$ urea, $0.02 \%$ $\mathrm{KH}_{2} \mathrm{PO}_{4}, 0.01 \% \mathrm{MgSO}_{4} \cdot 7 \mathrm{H}_{2} \mathrm{O}, 5 \mathrm{ppm} \mathrm{FeSO} \cdot 7 \mathrm{H}_{2} \mathrm{O}$, and $0.5 \mathrm{ppm} \mathrm{ZnSO}_{4} \cdot 7 \mathrm{H}_{2} \mathrm{O}$ in tap water.

Seed cultures were prepared by inoculating cells grown on potato-glucose agar slants into $300-\mathrm{ml}$ Erlenmeyer flasks containing $25 \mathrm{ml}$ of medium $\mathrm{A}$, followed by incubation at $25^{\circ} \mathrm{C}$ for 3 days on a rotary shaker $(220 \mathrm{rpm})$. The seed cultures $(2 \mathrm{ml})$ were transferred to $300-\mathrm{ml}$ Erlenmeyer flasks containing $25 \mathrm{ml}$ of the fermentation media. The flasks were shaken at $25^{\circ} \mathrm{C}$ for 7 days on the rotary shaker, unless otherwise indicated.

Fermentor experiments were done in a 5-1 Waldhof type jar fermentor (Marubishi model MD 300) with the following culture conditions: incubation temperature, $25^{\circ} \mathrm{C}$; agitation, $800 \mathrm{rpm}$, and aeration, $0.5 \mathrm{v} / \mathrm{v} / \mathrm{min}$. The seed culture $(300 \mathrm{ml})$ was inoculated into the jar fermentor containing 31 of medium $\mathrm{C}$.

* On study leave from the Microbiology Laboratory, Institute of Biological Sciences, University of the Philippines at Los Banos, College, Laguna, Philippines.

** To whom correspondence should be addressed.

Abbreviations: IT, itaconic acid; HP, $l$-2-hydroxyparaconic acid; ITT, $l$-itatartaric acid. 
Analytical methods. All the analytical methods were the same as reported in our preceding paper. ${ }^{1)}$

Interconversion between HP and ITT under acidic conditions. To measure the equilibrium constants and the reaction constants of the reversible reaction between $\mathrm{HP}$ and ITT, about $4 \mathrm{mM}$ solutions of HP or ITT were kept at different temperatures. The acidic solution of ITT was prepared by dissolving $2 \mathrm{mmol}$ of its sodium salt in $50 \mathrm{ml}$ of $0.8 \mathrm{~N} \mathrm{H}_{2} \mathrm{SO}_{4}$ and used as the starting acid. Portions were withdrawn at regular intervals and analyzed by HPLC.

\section{Results}

Effects of omission of $\mathrm{CaCO}_{3}$ on acidproduction

In our preceding paper, ${ }^{1)}$ acid productivity had been examined with a basal medium containing excess $\mathrm{CaCO}_{3}$. The effects of the omission of $\mathrm{CaCO}_{3}$ were examined with medium A. The omission of $\mathrm{CaCO}_{3}$ caused a low $\mathrm{pH}$ of about 2.5 , but resulted in satisfactory HP production (Fig. 1). The addition of $\mathrm{CaCO}_{3}$ to medium A resulted in slight lowerings of HP and marked increases of IT. These results showed that the omission of $\mathrm{CaCO}_{3}$ was favorable for this fermentation and especially
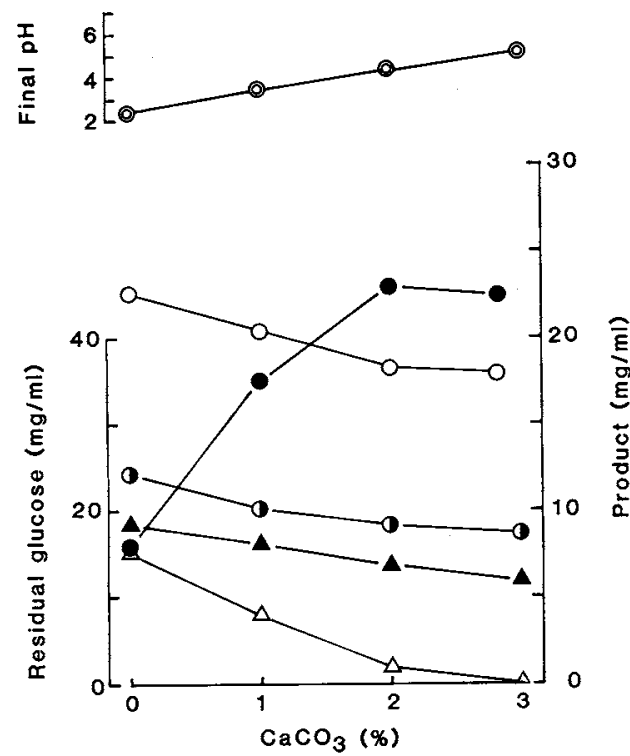

Fig. 1. Effects of Omission of $\mathrm{CaCO}_{3}$ on Acid Production.

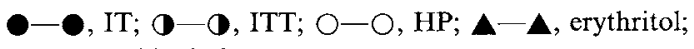
$\triangle-\triangle$, residual glucose. for product recovery.

Acid productivity in different strains under acidic conditions

The 13 strains of HP producers reported in our preceding paper ${ }^{1)}$ were cultured in medium A containing no $\mathrm{CaCO}_{3}$ (Table I). $U$. cynodontis K320 was selected as the best producer of HP under the acidic conditions and, hence, exclusively used in subsequent experiments.

\section{Effects of nitrogen sources}

The effects of nitrogen sources on acid production were examined with medium $\mathrm{A}$ in which $\mathrm{NaNO}_{3}$ was changed to different nitrogen sources ( $30 \mathrm{~mm}$ as nitrogen) (Table II). The use of neutral and alkaline nitrogen sources such as nitrates and urea caused final pHs of above 2 and gave high acid yields. However, the use of acidic nitrogen sources such as $\mathrm{NH}_{4} \mathrm{H}_{2} \mathrm{PO}_{4}$ and $\mathrm{NH}_{4} \mathrm{Cl}$ caused extremely low pHs (below 2) which consequently led to poor cell growth and low or no acid production but high accumulation of polyols. These facts showed that $\mathrm{pH} 2$ was critical for HP and ITT production by this strain, and further implied

Table I. Acid Productivity in Different STRAins UNDER ACIDIC Conditions

\begin{tabular}{lccccc}
\hline & & HP & ITT & IT & $\mathrm{C}_{\mathbf{4}}{ }^{a}$ \\
\cline { 4 - 6 } Strain no. & Final & & & \\
& $\mathrm{pH}$ & \multicolumn{5}{c}{$(\mathrm{mg} / \mathrm{ml})$} \\
\hline \multicolumn{4}{l}{ Ustilago cynodontis } \\
K320 & 2.25 & 25.4 & 7.3 & 10.4 & 4.5 \\
IFO 9758 & 2.34 & 23.5 & 6.3 & 12.5 & 5.5 \\
IFO 9727 & 2.37 & 19.7 & 5.2 & 26.6 & 3.7 \\
K322 & 2.49 & 18.0 & 4.4 & 15.0 & 1.9 \\
K321 & 2.31 & 16.5 & 4.4 & 20.2 & 1.0 \\
K472 & 2.52 & 16.1 & 3.6 & 28.2 & 7.2 \\
K471 & 2.52 & 14.5 & 3.6 & 27.4 & 4.1 \\
K470 & 2.50 & 13.6 & 3.3 & 28.4 & 5.8 \\
IFO 7530 & 2.80 & 13.0 & 3.3 & 9.5 & 4.2 \\
K474 & 2.68 & 11.1 & 1.7 & 18.8 & 3.0 \\
K473 & 2.63 & 11.1 & 1.3 & 19.6 & 9.1 \\
K323 & 5.00 & 2.5 & 0.6 & 3.5 & 5.0 \\
Ustilago rabenhorstina & & & & \\
IFO 8995 & 2.80 & 13.8 & 1.6 & 15.7 & 3.6 \\
\hline
\end{tabular}

a Erythritol. 
Table II.EFfects of Nitrogen Sources on Acid Porduction

\begin{tabular}{|c|c|c|c|c|c|c|c|}
\hline \multirow{2}{*}{ Nitrogen source ${ }^{a}$} & \multirow{2}{*}{$\begin{array}{c}\text { Final } \\
\mathrm{pH}\end{array}$} & \multirow{2}{*}{$\begin{array}{l}\text { Consumed } \\
\text { glucose } \\
(\mathrm{mg} / \mathrm{ml})\end{array}$} & \multirow{2}{*}{$\begin{array}{c}\text { Dry cell } \\
\text { weight } \\
(\mathrm{mg} / \mathrm{ml})\end{array}$} & $\mathrm{HP}+\mathrm{ITT}$ & IT & $\mathrm{C}_{4}{ }^{b}$ & $\mathrm{C}_{6}{ }^{c}$ \\
\hline & & & & \multicolumn{4}{|c|}{$(\mathrm{mg} / \mathrm{ml})$} \\
\hline $\mathrm{NaNO}_{3}$ & 2.30 & 115 & 14.0 & 39.2 & 9.4 & 7.2 & - \\
\hline Urea & 2.10 & 109 & 15.3 & 35.7 & 5.2 & 8.6 & - \\
\hline $\mathrm{NH}_{4} \mathrm{NO}_{3}$ & 2.12 & 102 & 14.3 & 32.6 & 2.9 & 8.0 & - \\
\hline $\mathrm{NH}_{4} \mathrm{H}_{2} \mathrm{PO}_{4}$ & 1.95 & 89 & 12.3 & 14.1 & 0.2 & 14.9 & 2.9 \\
\hline $\mathrm{NH}_{4} \mathrm{Cl}$ & 1.76 & 45 & 7.0 & - & - & 21.2 & 12.8 \\
\hline
\end{tabular}

a Supplied at $30 \mathrm{~mm}$ as N.

$b$ Erythritol.

- Mannitol.

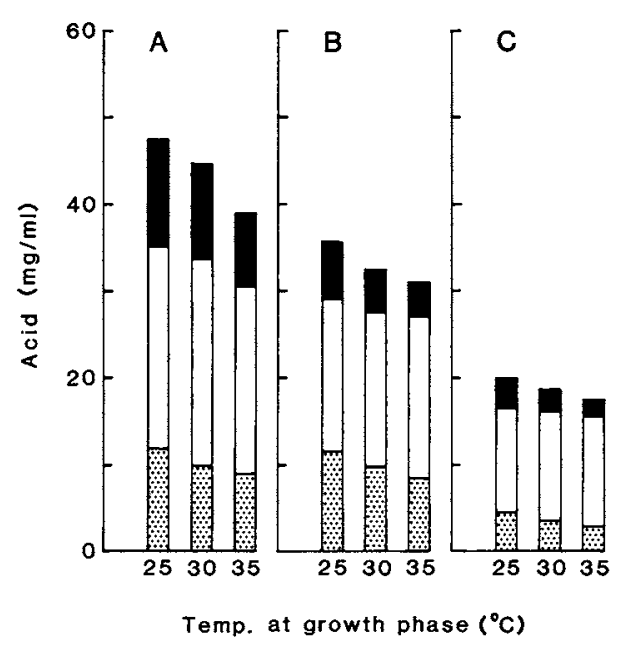

Fig. 2. Effects of Temperatures at Growth Phase and at Fermentation Phase on Acid Production.

The cultures were incubated on three shakers at 25,30 , and $35^{\circ} \mathrm{C}$ for 2 days (growth phase) and then some of them were transferred to the other shakers at 25 (A), 30 (B), and $35^{\circ} \mathrm{C}(\mathrm{C})$, and incubated for 6 days (fermentation phase). ITT; $\square$, HP; $\square$, IT.

that accumulated IT might be consumed under extremely acidic conditions (Fig. 1 and Table II).

\section{Effects of temperature and its shift}

Since acid production was not associated with cell growth, as described later, the effects of temperature on acid production were separately examined in the cell-growth phase and fermentation phase at 25,30 and $35^{\circ} \mathrm{C}$. The temperature in the fermentation phase was more important for acid production than that

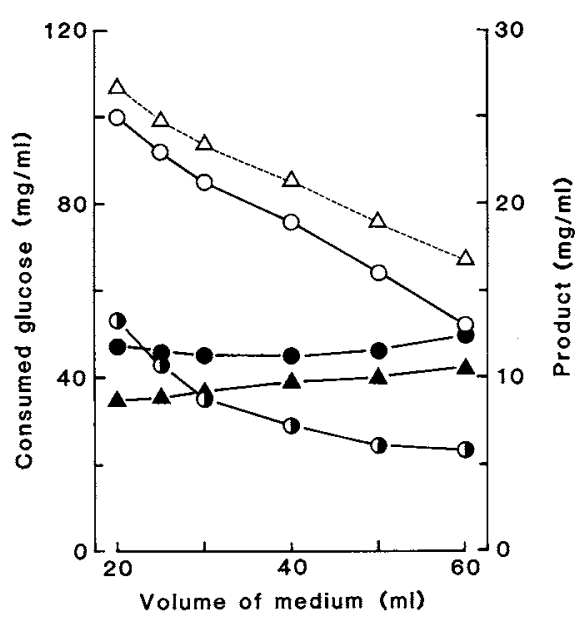

Fig. 3. Effects of Aeration on Acid Production.

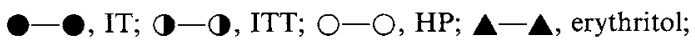
$\triangle--\triangle$, consumed glucose.

in the growth phase (Fig. 2). The lowest temperature $\left(25^{\circ} \mathrm{C}\right)$ throughout the cultivation period gave the highest acid yield. Cell growth, however, was best at $35^{\circ} \mathrm{C}$.

\section{Effects of aeration}

Different volumes $(20-60 \mathrm{ml})$ of medium A were put into $300-\mathrm{ml}$ Erlenmeyer flasks to examine the effects of aeration on acid production. Increasing the volume of the medium increased IT production but decreased HP and ITT production and glucose consumption (Fig. 3).

The effects of interruption of aeration ${ }^{5)}$ were examined by withdrawing the culture flasks from the shaker, standing them still for 5 to 
Table III. Effects of Supplementary Organic NUTRIENTS ON ACID PRODUCTION

\begin{tabular}{|c|c|c|c|c|}
\hline \multirow{2}{*}{$\begin{array}{c}\text { Organic } \\
\text { nutrient } \\
(\%)\end{array}$} & \multirow{2}{*}{$\begin{array}{c}\text { Dry cell } \\
\text { weight } \\
(\mathrm{mg} / \mathrm{ml})\end{array}$} & \multirow{2}{*}{$\underline{\mathrm{HP}+\mathrm{ITT}}$} & \multirow{2}{*}{$\frac{\mathrm{IT}}{(\mathrm{mg} / \mathrm{ml})}$} & \multirow[t]{2}{*}{$\mathrm{C}_{4}{ }^{a}$} \\
\hline & & & & \\
\hline None & 8.7 & 35.2 & 10.4 & 2.0 \\
\hline \multicolumn{5}{|l|}{$\begin{array}{l}\text { Yeast } \\
\text { extract }\end{array}$} \\
\hline 0.05 & 10.0 & 38.5 & 11.8 & 2.2 \\
\hline 0.1 & 12.0 & 39.8 & 10.7 & 5.8 \\
\hline 0.2 & 13.7 & 38.9 & 8.5 & 9.0 \\
\hline 0.3 & 16.0 & 23.9 & 4.6 & 17.7 \\
\hline \multicolumn{4}{|l|}{ Corn steep } & \\
\hline 0.1 & 9.3 & 35.6 & 11.6 & 8.4 \\
\hline 0.2 & 10.3 & 32.5 & 11.0 & 10.7 \\
\hline \multicolumn{5}{|l|}{ Rice bran } \\
\hline 0.1 & 10.3 & 36.7 & 11.0 & 7.4 \\
\hline 0.2 & 10.7 & 37.8 & 11.7 & 12.6 \\
\hline $\begin{array}{l}\text { Vitamin } \\
\text { mixture }^{b}\end{array}$ & 9.0 & 35.4 & 11.0 & 1.9 \\
\hline
\end{tabular}

$30 \mathrm{~min}$ and again shaking them. Even a short stop of aeration ( $5 \mathrm{~min}$ ) at the growth phase markedly lowered the acid yield. The inhibitory effect of the stop of aeration on acid production was more moderate in the fermentation phase.

\section{Effects of supplementary organic nutrients}

The effects of addition of organic nutrients on acid production were examined with medium $\mathrm{A}$ in which yeast extract was changed to different organic nutrients (Table III). The strain had no vitamin requirement for cell growth or acid production. The addition of yeast extract $(0.05-0.1 \%)$ accelerated fermentation speed, but its further addition $(0.2-$ $0.3 \%$ ) led to an increase of erythritol.

\section{Effects of addition of metal ions}

Preliminary experiments showed that the addition of $10 \mathrm{ppm} \mathrm{FeSO}_{4} \cdot 7 \mathrm{H}_{2} \mathrm{O}$ to the fermentation media increased acid production. The effects of addition of several metal ions at different concentrations were examined with medium A without yeast extract or Fe ion. The addition of $\mathrm{FeSO}_{4} \cdot 7 \mathrm{H}_{2} \mathrm{O}(5 \mathrm{ppm})$ and $\mathrm{ZnSO}_{4}$. $7 \mathrm{H}_{2} \mathrm{O}(0.5 \mathrm{ppm})$ was most effective on acid

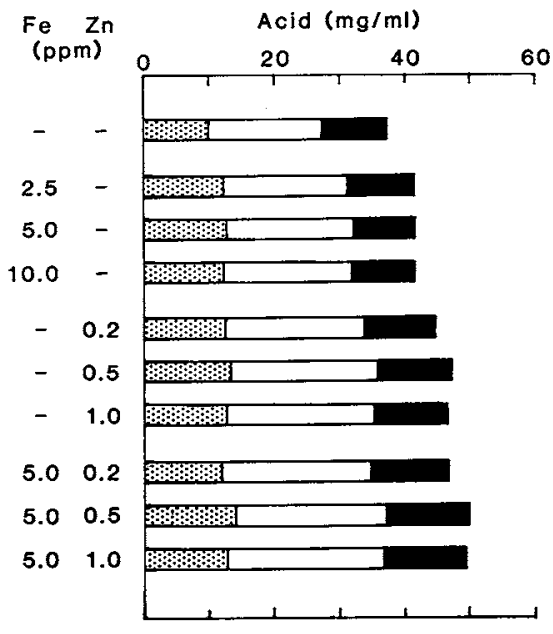

Fig. 4. Effects of Addition of Fe and $\mathrm{Zn}$ Ions on Acid Production.

图, ITT; $\square$, HP; $\mathbf{D}$, IT.

production and glucose consumption (Fig. 4). The addition of $\mathrm{CuSO}_{4} \cdot 4 \mathrm{H}_{2} \mathrm{O}(0.02-1.0 \mathrm{ppm})$ or $\mathrm{MnCl}_{2} \cdot 4 \mathrm{H}_{2} \mathrm{O}(0.5-5 \mathrm{ppm})$ was less effective or even inhibitory for acid production.

The addition of $\mathrm{Fe}$ and $\mathrm{Zn}$ ions was also most effective on acid production in media prepared with deionized water, but acid yield was about $80 \%$ of that obtained in media prepared with tap water. The further addition of $\mathrm{Mo}, \mathrm{Co}, \mathrm{Se}$, I or borate ion $(0.02-0.5 \mathrm{ppm})$ to the media prepared with deionized water had no stimulatory effect on acid production.

\section{Minimization of nutrients in culture medium}

To simplify the process of product recovery, it was desirable to minimize the concentrations of nutrients in media, because the unconsumed parts of the nutrients became impurities in product recovery. The effects of the concentrations of $\mathrm{K}$ and phosphate ions and $\mathrm{MgSO}_{4}$ on acid production were examined in medium $\mathrm{B}$ (Table IV).

The concentrations of phosphate from 0.5 to $4 \mathrm{~mm}$, added as $\mathrm{NaH}_{2} \mathrm{PO}_{4}$, gave similar total amounts of HP and ITT. At a low concentration of phosphate, $0.5 \mathrm{~mm}$, a slightly larger amount of IT was produced. The concentrations of $\mathrm{K}$ ion from 0.5 to $4 \mathrm{~mm}$, added as $\mathrm{KCl}$, had little effect on acid production. The 
Table IV. EFFects of Nutrients at Various Concentrations on Acid Production

\begin{tabular}{ccccc}
\hline \multirow{2}{*}{$\begin{array}{l}\text { Salt } \\
(\mathrm{mM})\end{array}$} & $\mathrm{HP}$ & $\mathrm{ITT}$ & $\mathrm{IT}$ & $\mathrm{C}_{4}{ }^{a}$ \\
\cline { 2 - 4 } & \multicolumn{4}{c}{$(\mathrm{mg} / \mathrm{ml})$} \\
$\mathrm{KCl}$ & & & \\
0.5 & 23.1 & 15.5 & 12.0 & 2.5 \\
1.0 & 23.3 & 15.7 & 12.2 & 2.3 \\
2.0 & 23.7 & 16.3 & 13.6 & 1.7 \\
4.0 & 23.9 & 16.5 & 14.0 & 1.6 \\
$\mathrm{NaH}_{2} \mathrm{PO}_{4}$ & & & & \\
0.5 & 19.6 & 14.6 & 26.3 & 1.6 \\
1.0 & 22.0 & 15.3 & 20.0 & 1.9 \\
2.0 & 22.8 & 16.3 & 14.5 & 1.8 \\
4.0 & 23.1 & 16.7 & 15.1 & 1.5 \\
$\mathrm{MgSO}_{4}$ & & & & \\
0.1 & 14.8 & 11.8 & 8.3 & 2.8 \\
0.2 & 20.6 & 14.6 & 11.5 & 2.0 \\
0.4 & 23.2 & 16.5 & 14.9 & 1.4 \\
0.8 & 23.5 & 16.5 & 15.0 & 1.4 \\
\hline
\end{tabular}

a Erythritol.

concentration of $\mathrm{MgSO}_{4} \cdot 7 \mathrm{H}_{2} \mathrm{O}$ was adequate at $0.4 \mathrm{~mm}$ (about $0.01 \%$ ) for HP and ITT production. From these results, the concentrations of minerals added in medium $\mathrm{A}$ were minimized as follows: $\mathrm{KH}_{2} \mathrm{PO}_{4}$, from 0.05 to $0.02 \% ; \mathrm{MgSO}_{4} \cdot 7 \mathrm{H}_{2} \mathrm{O}$, from 0.02 to $0.01 \%$.

\section{Course of fermentation in a 5-l jar fermentor}

Urea $(0.07-0.12 \%)$ was reexamined as a nitrogen source instead of $\mathrm{NaNO}_{3}$ to eliminate residual $\mathrm{Na}$ ion in the final broth, and the best result was obtained at $0.10 \%$ urea.

Figure 5 shows a typical course of HP and ITT fermentation in a 5-1 jar fermentor using medium $\mathrm{C}$ with $0.10 \%$ urea for product recovery. Acid production was not associated with cell growth. During the early stage of fermentation, HP was produced in larger amounts than IT, ITT, and erythritol. During the late stage of fermentation, however, the accumulated HP, IT, and erythritol were consumed, followed by an increase of ITT. The sum of the molar concentrations of HP and ITT had a tendency to decrease during more prolonged incubation.

Figure 6 shows the HPL chromatogram of culture filtrate after 12 days of incubation:

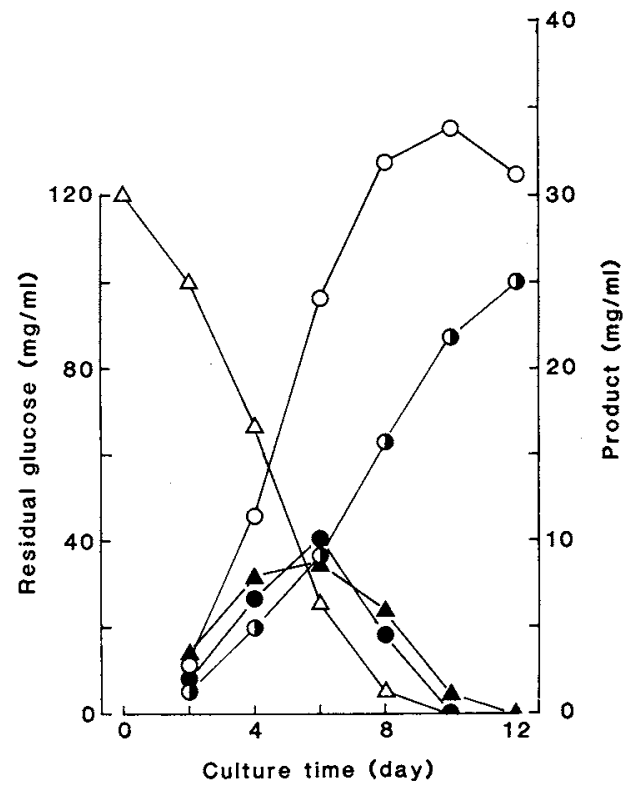

Fig. 5. Course of Fermentation in a 5-1 Jar Fermentor.

- IT; O-O. ITT; O-O, HP; $\boldsymbol{\Delta}-\boldsymbol{\Delta}$, erythritol; $\triangle-\triangle$, residual glucose.

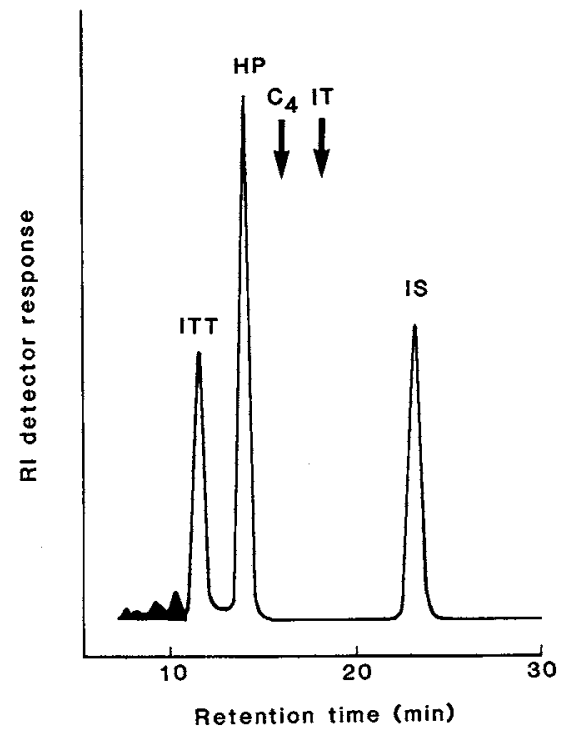

Fig. 6. HPL Chromatogram of Culture Filtrate after 12 days.

$\mathrm{C}_{4}$, erythritol; IS, internal standard (adipic acid). Shaded peaks imply impurities in product recovery.

glucose, IT, and erythritol were completely consumed and the sum of the peak areas corresponding to HP and ITT was calculated 
from the chart to be about $91 \%$ against the total peak areas of all components contained in the filtrate.

\section{Equilibrium reaction between HP and ITT under acidic conditions}

Since the fermented broths always contained both HP and ITT, information about the kinetics of their equilibrium reactions was necessary for an efficient recovery process.

The equilibrium reaction between HP and ITT can be represented as follows: ${ }^{6)}$

$$
\begin{aligned}
& \mathrm{HP}+\mathrm{H}_{2} \mathrm{O} \underset{k_{2}}{\stackrel{k_{1}}{\rightleftarrows}} \mathrm{ITT} ; \\
& K=([\mathrm{ITT}] /[\mathrm{HP}])_{t=\infty}=k_{1} / k_{2} ; \\
& k_{1}+k_{2}=1 / t\left[\ln X_{\mathrm{e}} /\left(X_{\mathrm{e}}-X\right)\right],
\end{aligned}
$$

where $k_{1}=$ the first order reaction constant for the forward direction $\left(\mathrm{min}^{-1}\right), k_{2}=$ the first order reaction constant for the reverse direction $\left(\mathrm{min}^{-1}\right), X=$ the molar concentration of converted acid at time $t$ and $X_{\mathrm{c}}=$ the equilibrium molar concentration of converted acid at infinite time.

These constants were measured at different temperatures under acidic conditions. The reversible reactions for the forward and the reverse directions at the same temperature $(30$, 60,80 or $100^{\circ} \mathrm{C}$ ) reached the same state of

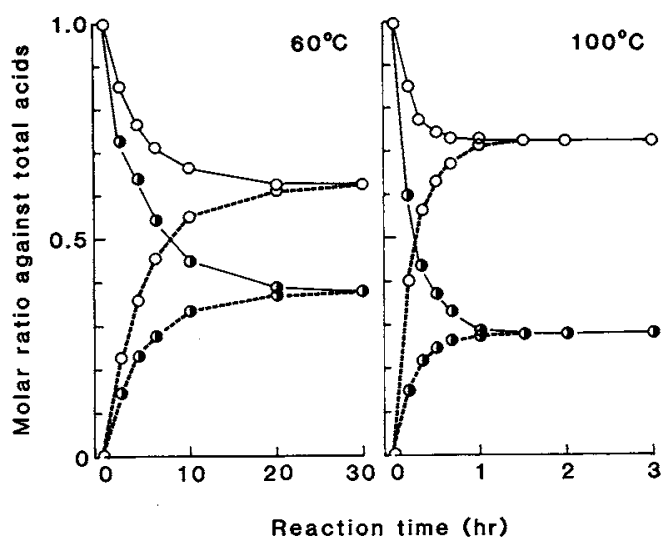

Fig. 7. Interconversions between $\mathrm{HP}$ and ITT under Acidic Conditions at 60 and $100^{\circ} \mathrm{C}$

O, HP; I. ITT. Solid and broken lines represent the decreases of the starting acids and the increases of the converted acids, respectively. equilibrium. Figure 7 shows the courses of the reactions at 60 and $100^{\circ} \mathrm{C}$ as examples.

Figure 8 shows the Arrhenius plot of the values of $K$. When the values of $\ln X_{\mathrm{e}} /\left(X_{\mathrm{e}}-X\right)$ were plotted against time, straight lines were obtained in every case. Figure 8 also shows the calculated values of $k$ at different temperatures.

\section{Recovery of HP from culture broth}

The jar broth (2.51) was filtered through a layer of kieselguhr. The filtrate was treated with $5 \mathrm{~g}$ of active charcoal and then concentrated to a syrup under reduced pressure. The syrup was further heated to lactonize ITT to $\mathrm{HP}$ at $70^{\circ} \mathrm{C}$ for about $6 \mathrm{hr}$ under reduced pressure. The remaining solid mass $(144 \mathrm{~g})$ was proved to be

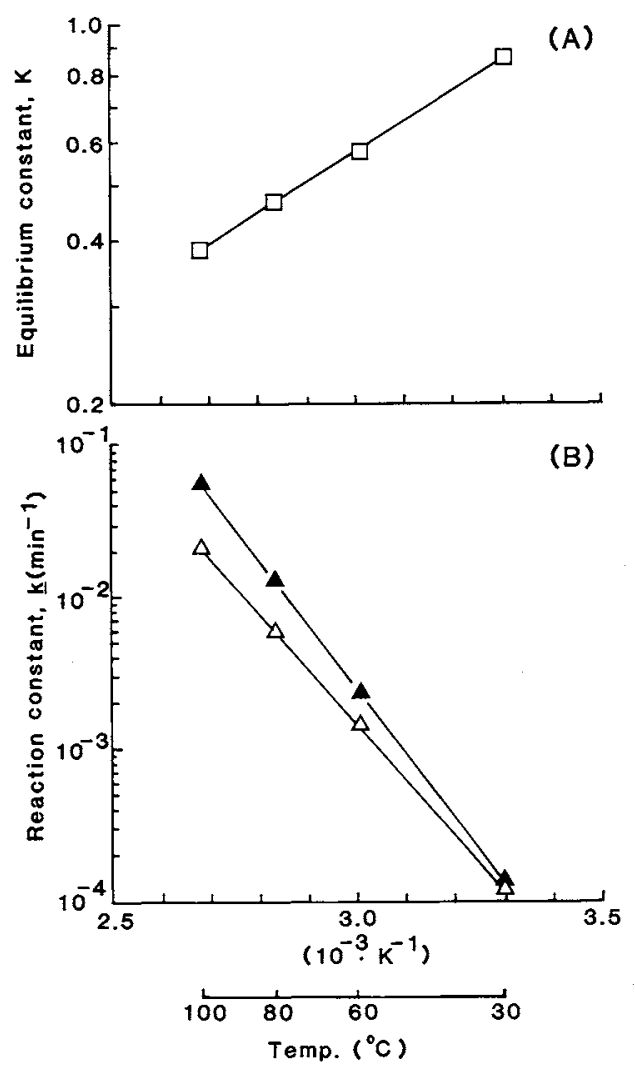

Fig. 8. (A) Arrhenius Plot of Equilibrium Constants, $K$, and (B) Reaction Velocity Constants, $k$, for Reversible Reactions between HP and ITT.

$\square-\square$, equilibrium constant, $K=([\mathrm{ITT}] /[\mathrm{HP}])_{t=\infty}=$ $k_{1} / k_{2} ; \triangle-\triangle, k_{1}=$ the first order reaction constant from HP to ITT; $\boldsymbol{\Delta}-\boldsymbol{\Delta}, k_{2}=$ the first order reaction constant from ITT to HP. 
HP (about $92 \%$ in purity) by HPLC. The crushed solid mass was dissolved in hot ethyl acetate $(300 \mathrm{ml})$ with vigorous agitation. The insoluble parts were removed by decantation and the solvent layer was concentrated and dried up. HP (122 g) was obtained as a crystalline solid mass (about $96 \%$ in purity). HP was further purified by crystallization with ethyl acetate and chloroform.

Sodium salt of ITT was prepared from the crystalline solid mass or the recrystallized HP. A portion of the solid mass $(146 \mathrm{mg})$ was dissolved in about $20 \mathrm{ml}$ of cold $\mathrm{H}_{2} \mathrm{O}$ and titrated with $0.05 \mathrm{~N} \mathrm{NaOH}$ prepared from an original $5 \mathrm{~N} \mathrm{NaOH}$ in a cold state. Neutralization equivalent, Found: 149. Calcd. for $\mathrm{C}_{5} \mathrm{H}_{6} \mathrm{O}_{5}$ : 146. $\mathrm{p} K_{\mathrm{a}}=2.78$. From this titer, the necessary volume of the original $5 \mathrm{~N} \mathrm{NaOH}$ was calculated to neutralize the solution of the solid mass $\left(14.6 \mathrm{~g}\right.$ in $100 \mathrm{ml} \mathrm{H}_{2} \mathrm{O}$ ) as a monobasic acid. Double calculated volume of the $5 \mathrm{~N}$ $\mathrm{NaOH}$ was added to the solution. The mixed solution was heated in a boiling water bath for about $10 \mathrm{~min}$ to saponify $\mathrm{HP}$, concentrated under reduced pressure, and dried up in an oven at $105^{\circ} \mathrm{C}$ ( $20.5 \mathrm{~g}$ of residue). The residue, that is, sodium ITT showed $\mathrm{p} K_{\mathrm{a} 1}=3.15$ and $\mathrm{p} K_{\mathrm{a} 2}=4.92$ in back titration with $0.1 \mathrm{~N} \mathrm{H}_{2} \mathrm{SO}_{4}$, and the acidified solution gave no peak of HP on HPLC.

\section{Discussion}

The accumulation of mixtures of ITT and HP as minor by-products was already reported in IT fermentation by Aspergillus terreus ${ }^{2,7)}$ and $A$. itaconicus. ${ }^{3)}$ The acids, however, were isolated in small amounts for the purpose of their characterization only after laborious procedures including continuous ether extraction. ${ }^{2,3)}$ Stodola et al. ${ }^{2)}$ separated the acids as methyl esters by fractional distillation and then obtained the optically active benzylamide of ITT in crystals from the methyl esters. Kobayashi et al. ${ }^{3)}$ initially separated ITT as the calcium salt from the culture broth and then obtained HP as optically active prisms in a low yield.

The mixture of HP and ITT was a major product in this fermentation by $U$. cynodontis. IT and erythritol, as minor ones, were found to be consumed after glucose had been completely used. Thus, after about 12 days of incubation, the fermented broth contained only HP and ITT; this fact led to easy recovery of these acids.

The initial concentrations of nutrients in fermentation media were limited to minimize the remaining amounts of the nutrients as impurities in the final culture broths. From the results, HP was easily recovered as a crystalline mass (about $96 \%$ in purity) in about $90 \%$ molar yield based on total amounts of HP and ITT by the simple process consisting of concentration, lactonization of ITT to HP, and ethyl acetate extraction. Sodium salt of ITT was easily prepared by saponification of the recovered HP. Optically active HP and Na-ITT will be available as new raw materials for chemical industries.

Acknowledgments. We are grateful to Professor $\mathrm{T}$. Nakahara of our institute for the useful advice and to $\mathrm{M}$. Takimoto for her technical assistance.

\section{References}

1) E. D. Guevarra and T. Tabuchi, Agric. Biol. Chem., 54, 2353 (1990).

2) F. H. Stodola, M. Friedkin, A. J. Moyer and R. D. Coghill, J. Biol. Chem., 161, 739 (1945).

3) T. Kobayashi, T. Tabuchi and K. Kitahara, Nippon Nōgeikagaku Kaishi, 35, 541 (1961).

4) N. J. W. Kreger-van Rij, "The Yeasts, a Taxonomic Study," 3rd Revised and Enlarged Ed., Elsevier Science Publishers B. V., Amsterdam, 1984, p. 79.

5) V. F. Pfeifer, C. Vojnovich and E. N. Heger, Ind. Eng. Chem., 44, 2975 (1952).

6) T. Tabuchi, I. Nakamura and T. Kobayashi., $J$. Ferment. Technol., 55, 37 (1977).

7) J. Jakubowska, A. Nowakowska-Waszczuk, E. Lasota-Dulkowska, Z. Zakowska and B. Sobocka, Acta Microbiol. Pol., 16, 227 (1967). 